\title{
Lean-Green Manufacturing Practices and Their Link with Sustainability: A Critical Review
}

\author{
Wadhah Abualfaraa ${ }^{1, *}$, Konstantinos Salonitis ${ }^{1}{ }^{1}$, Ahmed Al-Ashaab ${ }^{1}$ and Maher Ala'raj ${ }^{2} \mathbb{C}$ \\ 1 School of Aerospace, Transport and Manufacturing, Cranfield University, Bedford MK43 0AL, UK; \\ k.salonitis@cranfield.ac.uk (K.S.); a.al-ashaab@cranfield.ac.uk (A.A.-A.) \\ 2 Department of Information Systems, College of Technological Innovation, Zayed University, \\ Dubai 19282, UAE; maher.alaraj@zu.ac.ae \\ * Correspondence: w.abualfaraa@cranfield.ac.uk
}

Received: 15 November 2019; Accepted: 23 January 2020; Published: 29 January 2020

\begin{abstract}
The current rapidly changing and highly competitive market has put companies under a great pressure towards adopting sustainable practices, in terms of keeping a healthy balance among economic, environmental and social performances. In this context, the lean-green manufacturing approach, which combines lean practices focused on customers' demand, and green practices focused on reducing the business' environmental impact, has gained popularity. Nevertheless, the lean-green manufacturing is still a relatively new practice, lacking a clear and structured research definition, and of significant evidence of successful cases in the practice. In this paper, a literature review is conducted to identify the actual possibility of combining lean and green practices, the current trends for implementing such combination and the potential sustainability improvements such implementation can lead. It is the authors' intention that the findings analysed in this paper can contribute to the state-of-the-art of lean-green manufacturing and provide practitioners with a useful tool towards developing effective strategies for its deployment.
\end{abstract}

Keywords: lean manufacturing; green manufacturing; lean-green manufacturing; sustainability; systematic literature review

\section{Introduction}

For several years, manufacturing practices have been mainly focused on satisfying or creating needs, while keeping competitiveness in terms of product quality, time to market and innovation. In particular, lean manufacturing, first introduced for the automotive industry in Japan, has largely been considered to be one of the most influential manufacturing paradigms. Lean manufacturing provides organisations with the tools to improve their competitiveness based on increasing value to customers, in terms of productivity, efficiency, quality and costumers' satisfaction, by reducing the resources consumption via waste elimination. These kind of manufacturing philosophies based on customers' demand, together with the improved people living's standards, have led to a growing product demand, fulfilled by a huge amount of produced goods, ending up in an increasing generation of pollution and wastes. In this context, companies are urged to become more proactive regarding their environmental and social stance, moving towards more sustainable manufacturing practices, in terms of the well-known Triple-Bottom-Line (TBL) sustainability conceptualisation [1] (shown in Figure 1), which suggests that a company would be able to achieve sustainable results provided it is capable of improving environmental, social and economic performances simultaneously. In this line, researchers have started to consider lean manufacturing with a renewed interest towards developing greener solutions capable not only of minimising wastes, but also of reducing, by extending, modifying 
and updating lean methodologies, the environmental and social negative impacts of the traditionally used industrial practices [1-11].

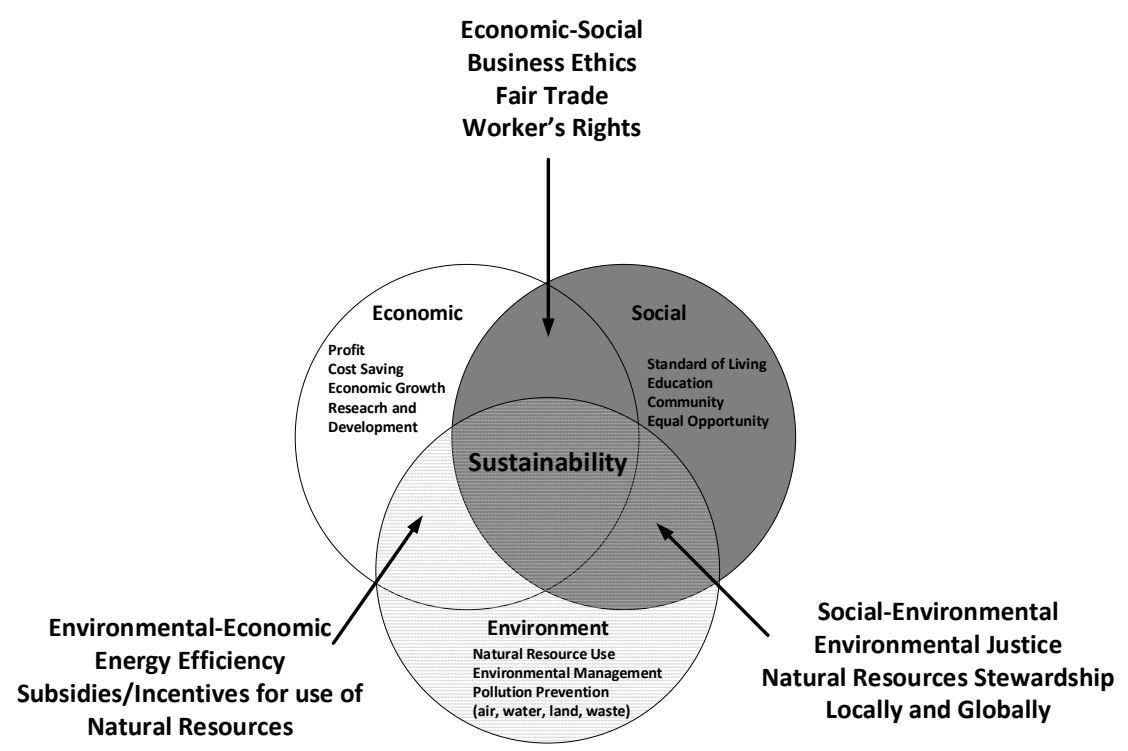

Figure 1. The three pillars of sustainability performance defined in [1].

Although some promising results have been reported in the literature by adapting lean practices to address greener objectives $[3,4,6,12]$, there are many researchers that argue that lean practices have not reached the maturity level required to ensure sustainability yet $[4,13]$. In this line, they have suggested that, in order to be able to achieve sustainable results, the implementation of green manufacturing practices should also be considered [9]. Green practices are focused on reducing hazardous emissions, getting rid of the consumption of wasteful resources, recycling, and minimising health risks throughout the entire manufacturing process, by minimising the environmental footprint during the whole product life cycle [14]. Nevertheless, although green practices can fulfil the market's greener expectations by extending the "waste reduction" idea proposed by lean manufacturing, in the sense of reducing waste, pollution, raw material usage and energy consumption, the relationship between green practices and the economic performance remains unclear. On one hand, there are researchers that agree that green strategies, such as Design for Environment (DfE) or Green Supply Chain Management (GSCM), optimise the interaction of the economic and the environmental systems, producing a sustainable development and enterprise integration [15-18]. On the other hand, there are researchers that state that green practices are not enough to ensure sustainability [19]. Moreover, practitioners often argue that green practices can be a burden for reaching improvements regarding design and production processes [20,21]. In this conflicting context, researchers and practitioners agree that neither lean nor green practices have demonstrated to be able to keep the expected balance among economic, environmental and social aspects when implemented individually [13,22-24]. Then, in order to fulfil the current sustainability requirements, the combination of lean and green practices so that their strengths can be enhanced, and their weaknesses can be mitigated, have been proposed.

To combine lean and green manufacturing approaches is a very complex and challenging task [10,14,25-28]. In addition, although research regarding the individual implementation of lean and green manufacturing approaches abounds, there is still much research to be conducted regarding their integration into a single approach $[9,28]$. Moreover, in a recent literature review study presented in [26], conflicting results have been reported regarding whether green and lean practices are actually suitable to work together. On one hand, there are researchers that favour their integration $[26,28]$, arguing that they can support each other, generating a synergetic effect, in the sense that their strengths can be enhanced while their weaknesses can be mitigated. On the other hand, there are the ones who do not favour their integration [29,30], arguing that both approaches differ in their main objectives, 
being sometimes incompatible. In this conflicting context, further research needs to be conducted towards evaluating the actual possibility of integrating the lean and green approaches, the potential of the combined approach and its influence on sustainable aspects in terms of economic, environmental and social performances. In order to fill these research gaps, a Systematic Literature Review (SLR) is conducted in this paper. The main contributions of this paper are as follows:

- $\quad$ Provide a deep insight into the current trends in lean and green approaches analysing their main similarities, differences, compatibilities and conflict of interest in order to evaluate whether they can be integrated into a single combined approach.

- Identify the most relevant currently available lean-green combination strategies in the literature, highlighting their main gaps, benefits and limitations.

- Evaluate the capability of the lean-green combined approach of fulfilling the current sustainability requirements in terms of improving economic, environmental and social performances simultaneously.

- Identify success factors to improve sustainable results based on the lean-green approach.

The remainder of the paper is organised as follows. In Section 2, the research method used in this paper to conduct the literature review, is described. In Section 3, a synthesis of the SLR results is presented. Section 4 is devoted to the analysis and discussion of the findings of the SLR. Finally, in Section 5 the concluding remarks are discussed.

\section{Research Method}

A well conducted literature review should be able to give researchers a clear picture regarding the main issues of the area in order to identify the current gaps in the literature and close the related subjects where plethora of research has already been reached [31]. In this paper, a SLR, which consists of a precise, transparent, explicit, and reproducible method, is conducted. According to [32], it is crucial to clearly explain how the SLR is conducted for the sake of transparency. The SLR conducted in this paper, follows a series of well-structured steps introduced in [33]. First of all, the research questions that are intended to be answered by the SLR are formulated. In a second step, the different contributions are located. This phase includes the choice of specific search terms and databases. Then, these contributions are selected according to an inclusion/exclusion criterion, in order to be evaluated and summarised. Finally, the analysis of all the selected contributions is carried out in order to draw the corresponding conclusions and propose further research directions based on them. Table 1 summarises the different steps involved in the SLR conducted in this paper.

Table 1. Systematic Literature Review (SLR) description.

\begin{tabular}{|c|c|}
\hline SLR Phase & Description \\
\hline Research Question Formulation & The main research questions intended to be answered are defined. \\
\hline Location and Selection of Studies & $\begin{array}{l}\text { - Definition and selection of the used Electronic Databases (EDs). } \\
- \text { Definition of search time period. } \\
\text { - Definition and choice of the used inclusion/exclusion criterion. } \\
- \text { Definition of the used search strings. }\end{array}$ \\
\hline Synthesis of the Studies & Thematic analysis of the selected articles. \\
\hline Analysis of the Studies & $\begin{array}{l}\text { The selected articles are analysed towards finding research gaps and } \\
\text { identifying significant patterns. }\end{array}$ \\
\hline Report of the results & The results are presented. \\
\hline
\end{tabular}

\subsection{Research Questions}

The SLR conducted in this paper is aimed at giving a deep insight into the current trends in lean and green manufacturing in terms of their actual capability of being integrated into a single 
approach, making especial focus on the potential that such combination can have towards improving the whole company's sustainability performance. In this line, the following research questions should be answered:

- Which are the actual possibilities of integrating lean and green practices into a combined approach?

- Which are the most relevant strategies proposed in the literature to implement the combined lean-green approach?

- What is the actual (and expected) impact of implementing the combined lean-green approach in the companies' sustainability performance?

\subsection{Location and Selection of Studies}

\subsubsection{Databases}

The location of the relevant contributions related to the research questions introduced in Section 2.1 has been carried out resorting to different database resources. In particular, the following EDs have been used:

- $\mathrm{ACM}$ (dl.acm.org)

- Elsevier (sciencedirect.com)

- Emerald (emeraldinsight.com)

- Google Scholar (scholar.google.com)

- IEEE (ieeexplore.ieee.org)

- Scopus (scopus.com)

- $\quad$ Springer (springerlink.com)

- Taylor \& Francis (T\&F) (tandfonline.com)

- Wiley (onlinelibrary.wiley.com)

\subsubsection{Time Period}

Although the sustainability concept has largely been discussed, it was not until the Brundtland's report in 1987 that the World Commission on Environment and Development (WCED) provided a widely accepted definition of sustainability as "the development that meets the needs of the present without compromising the ability of future generations to meet their needs" [34]. Since then, the amount of contributions regarding environmental and sustainable aspects of manufacturing has significantly increased. In addition, several researchers highlight the release of environmental standards such as the ISO 14,001 in 1996 as an important turning point in companies' sustainability awareness [9]. Taking this into account, and in order to focus on the most recent contributions to the area, the period from 2000 to 2018 will be considered to collect the articles.

\subsubsection{Search Strings}

The main aim of the SLR conducted in this paper is to analyse the compatibility of the currently available lean and green practices, in terms of similarities, differences and synergy, towards evaluating the possibility of combining them into a single approach capable of achieving sustainable results. The used search strings should allow properly covering the addressed topic ensuring the completeness of the literature exploration. In this line, the used search strings take as initial research points the following topics:

- Compatibility between lean and green manufacturing practices: similarities, differences and synergy.

- Main strategies towards implementing the combined lean-green approach.

- The lean-green approach and its potential to achieve further improvements in the companies' sustainability performance. 
Based on these starting points, the used search strings in this paper include (lean and green compatibility), (lean vs. green), (lean-green manufacturing), (lean-green manufacturing trends), (sustainable lean manufacturing), (sustainable green manufacturing), (sustainable lean-green manufacturing), (lean-green manufacturing sustainability impact). When using the proposed search strings, some duplicated articles were found. The duplicated articles were discarded, and the search stopped at the point where duplicated articles keep appearing and no new articles were found. Then, the resulting articles are filtered according to their publication date using the time period described in Section 2.2.2. Finally, the abstracts of the remaining articles are analysed towards deciding whether they are relevant to the addressed topic, removing the ones that are not related to the addressed topic or that are out of the scope of the SLR conducted in this paper.

\subsubsection{Search Results}

Applying the search criteria described in Sections 2.2.1-2.2.3 resulted in a total of 45 selected articles. Among them, 34 (75.5\%) are from International Journals, 10 (22.2\%) are from Proceedings of International Conferences, and one (2.2\%) is from a book, as shown in Figure 2.

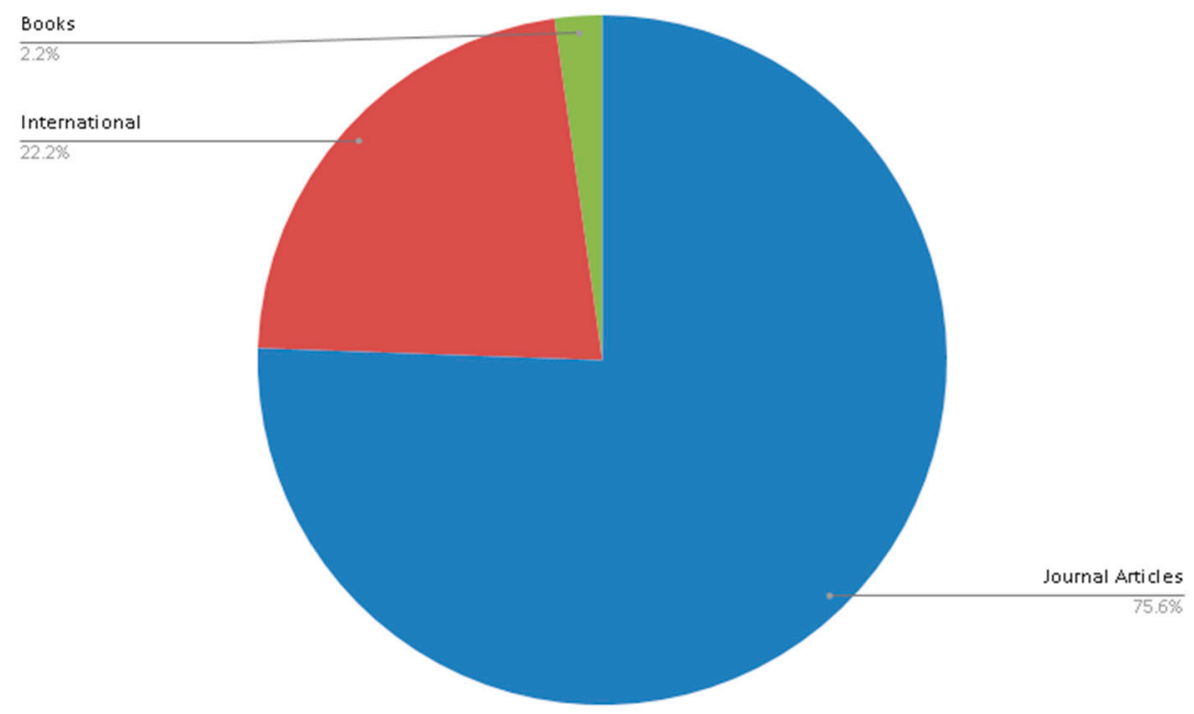

Figure 2. Proportion of journal, conference and book articles in the SLR.

This shows that international journals are currently the preferred option by researchers to divulgate their research findings. This is probably due to the widely accepted idea that such type of publications enjoy a higher status than, for instance, the conference proceedings [32]. The most recurrent journals in the conducted search are the Journal of Cleaner Production (https://www.journals.elsevier.com/ journal-of-cleaner-production) (Impact Factor (IF) 2018: 6.395, SCImago Journal Rank (SJR) 2018: 1.620) and the Journal of Production Economics (https://www.journals.elsevier.com/international-journal-ofproduction-economics) (IF 2018: 4.998, SJR 2018: 2.475), with 11 (24.4\%) and 4 (8.8\%) contributions among the selected ones, respectively. This allows some observations. Firstly, the high IF and SJR indices of these journals validates the relevancy of the selected articles and suggests that researchers tend to publish their contributions in specialised journals, which is in line with the findings in [35]. Secondly, researchers working on lean-green manufacturing prefer to publish their contributions in journals that are associated with a cleaner production concept, such as the Journal of Cleaner Production, which can be associated with a greener, safer and healthier production, rather than publishing in journals such as the Journal of Production Economics which are related to a traditional production concept. Finally, Figure 3 shows the number of selected articles per year. From Figure 3 it can be observed that this number has significantly increased in the last decade. 


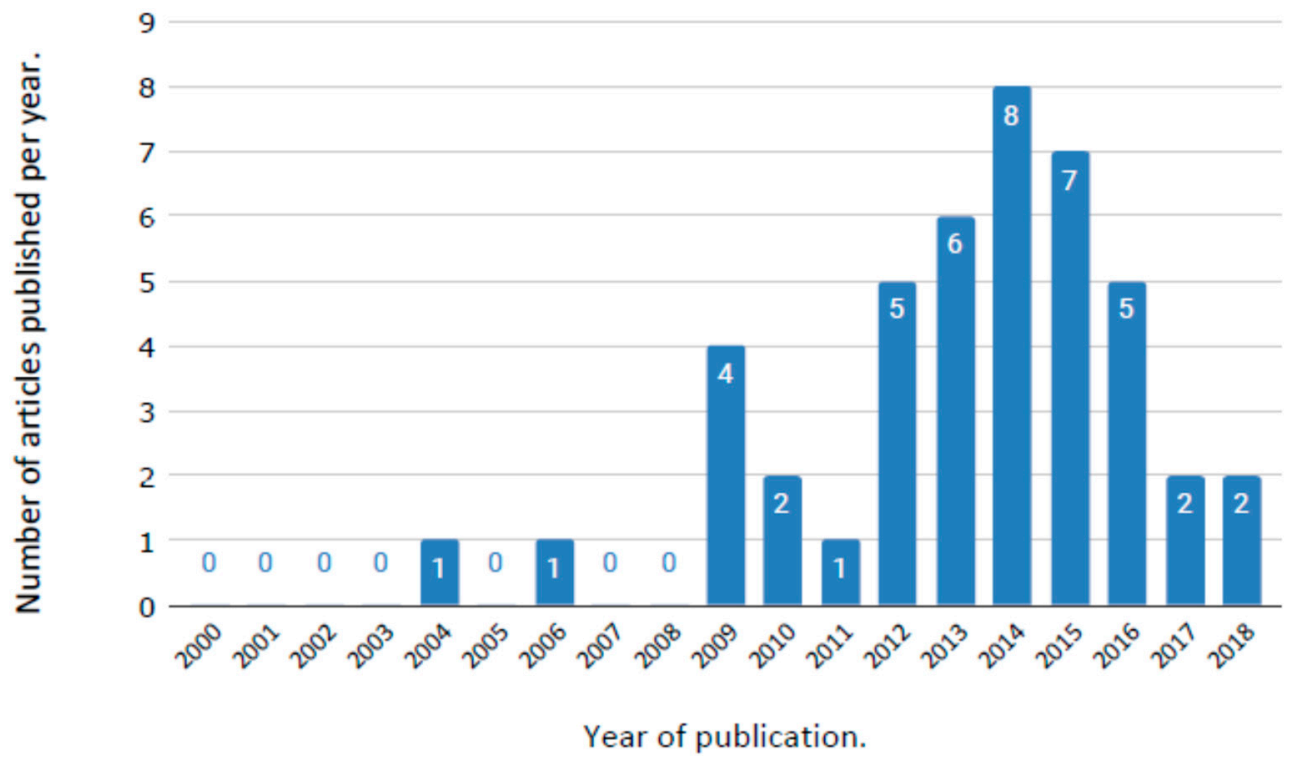

Figure 3. Number of articles per year.

\section{Preliminary Analysis of the Studies}

Different approaches have been proposed in the literature to analyse and synthesise the results obtained by SLRs [10,36]. In [36], different methods for the synthesis of qualitative research are compared in terms of issues of context and rigor. According to [36], the thematic synthesis is a well-suited synthesis method capable of keeping an explicit and transparent link between conclusions and the text of primary studies, preserving the most important principles of the systematic reviews. In this paper, a thematic synthesis is performed in order to identify, classify and analyse the most important subjects addressed by the 45 selected articles. Table 2 show the Systematic Literature Matrix (SLM) [10] where the selected articles are classified into different categories according to their main aim and focus. Firstly, the way in which the lean-green issue is addressed in each article is considered. In this sense, whether articles address lean-green manufacturing by performing a literature review, a conceptual analysis, a research application or a case/empirical study, is evaluated. As discussed in Section 1, since the lean-green manufacturing is a new manufacturing concept, there is still too much research to conduct in the field. In this line, the proposed classification allows evaluating which direction, theoretical, in terms of conceptual analyses; qualitative, in terms of literature reviews; or practical, in terms of research applications and case/empirical studies, needs to be further and deeper investigated. Secondly, the content of the articles is analysed in order to find out which of the main concerns of this paper they are focused on. In this way, it is intended to classify the articles according to their link with the research questions formulated in Section 2.2.1. In particular, the articles concerning the first research question regarding the actual possibilities of integrating lean and green practices into a combined approach are classified into the "lean vs. green analysis" and "lean-green synergies" categories. The articles concerning the second research question regarding the currently proposed strategies to implement the combined lean-green approach are classified into the "lean-green implementation" category. Finally, the articles concerning the third research question regarding the impact of implementing the combined lean-green approach in the sustainability performance are classified into the "impact on performance" and "sustainability" categories. The proposed categories are described as follows:

- Conceptual Analysis: Articles in this category address the lean and green practices integration from a theoretical point of view. In general, these kinds of analyses are found in books.

- Literature Review: Literature reviews focus on collecting and discussing the most recent and relevant contributions regarding integrating lean and green practices. They can address the 
integration issues either by performing a lean vs. green analysis, or by proposing strategies to implement it.

- Research Application: This category includes articles where authors propose different models and practical approaches to actually implement the lean-green approach.

- Case Study/Empirical Study: These types of studies are held within the companies' manufacturing context. Some of them resort to surveys, while some others perform experimental tests.

- Lean vs. Green Analysis: Articles classified in this category study the actual possibility of combining lean and green practices based on their main similarities and differences.

- Lean and Green Synergy: These articles evaluate to what extent lean and green practices can generate actually be implemented together within a synergetic environment, in the sense that their strengths can be enhanced while their weaknesses can be disguised.

- Lean-green Implementation: This category aims to gather the proposed approaches to practically implement the lean-green combination.

- Impact on Performance: This category shows which are the main pursued objectives behind implementing the combined lean-green approach.

- Sustainability: In this category, it is intended to include articles that evaluate the actual impacts of the combined approach to the sustainability performance and to what extent (and how) further improvements can be achieved when the combination approach is implemented. 
Table 2. SLM for the 45 selected articles.

\begin{tabular}{|c|c|c|c|c|c|c|c|c|c|}
\hline Ref & Conceptual Analysis & Lit. Review & Research App. & Case Study/Empirical Appl. & Lean vs. Green Analysis & $\begin{array}{c}\text { Lean and Green } \\
\text { Synergy }\end{array}$ & $\begin{array}{c}\text { Lean-Green } \\
\text { Implementation }\end{array}$ & $\begin{array}{l}\text { Impact on } \\
\text { Performance }\end{array}$ & Sustainability \\
\hline [37] & & $\mathrm{x}$ & & & $\mathrm{x}$ & $\mathrm{x}$ & & & \\
\hline [38] & & & $\mathrm{x}$ & & & & $\mathrm{x}$ & & $x$ \\
\hline [39] & & & & $\mathrm{x}$ & & & & $\mathrm{x}$ & $\mathrm{x}$ \\
\hline [40] & & $\mathrm{x}$ & & $\mathrm{x}$ & & & & $\mathrm{x}$ & $\mathrm{x}$ \\
\hline [41] & & & $\mathrm{x}$ & & & & $\mathrm{x}$ & $\mathrm{x}$ & \\
\hline [42] & & & & $\mathrm{x}$ & & & $\mathrm{x}$ & $\mathrm{x}$ & $\mathrm{x}$ \\
\hline [43] & & & $\mathrm{x}$ & & & & $\mathrm{x}$ & & $\mathrm{x}$ \\
\hline [11] & & $\mathrm{x}$ & & & $\mathrm{x}$ & $\mathrm{x}$ & & & $\mathrm{x}$ \\
\hline [44] & $\mathrm{x}$ & & & $\mathrm{x}$ & & & $\mathrm{x}$ & & $\mathrm{x}$ \\
\hline [45] & & $\mathrm{x}$ & $\mathrm{x}$ & $\mathrm{x}$ & & & $\mathrm{x}$ & & $\mathrm{x}$ \\
\hline [46] & & & & $\mathrm{x}$ & & & $\mathrm{x}$ & & $\mathrm{x}$ \\
\hline [47] & & & & $\mathrm{x}$ & $\mathrm{x}$ & $\mathrm{x}$ & & $\mathrm{x}$ & \\
\hline [28] & & & & $\mathrm{x}$ & & & $\mathrm{x}$ & $\mathrm{x}$ & $\mathrm{x}$ \\
\hline [48] & & & $\mathrm{x}$ & $\mathrm{x}$ & & & $\mathrm{x}$ & & \\
\hline [49] & $\mathrm{x}$ & & & & $\mathrm{x}$ & & & & \\
\hline [50] & & & $\mathrm{x}$ & & & & $\mathrm{x}$ & & $\mathrm{x}$ \\
\hline [51] & & & & $\mathrm{x}$ & & & & & \\
\hline [10] & & $\mathrm{x}$ & & & $\mathrm{x}$ & $\mathrm{x}$ & $\mathrm{x}$ & & $\mathrm{x}$ \\
\hline [52] & & & $\mathrm{x}$ & $\mathrm{x}$ & & & $\mathrm{x}$ & & \\
\hline [53] & $\mathrm{x}$ & & & & $\mathrm{x}$ & & & & \\
\hline [54] & & & & $\mathrm{x}$ & & & $\mathrm{x}$ & $\mathrm{x}$ & $\mathrm{x}$ \\
\hline [9] & & $\mathrm{x}$ & & & $\mathrm{x}$ & $\mathrm{x}$ & & & $\mathrm{x}$ \\
\hline [7] & $\mathrm{x}$ & & & & $\mathrm{x}$ & & & & $\mathrm{x}$ \\
\hline [55] & & & $x$ & & & & $x$ & & $x$ \\
\hline [56] & & $x$ & & & & $x$ & & & $x$ \\
\hline [57] & & & $x$ & & & & $x$ & & $x$ \\
\hline [58] & & & $x$ & & & & $x$ & $x$ & $x$ \\
\hline [59] & & $x$ & & & $x$ & $x$ & & & \\
\hline [60] & & & $x$ & & & & $x$ & & \\
\hline [61] & $x$ & & & & $x$ & $x$ & & & \\
\hline [26] & & $x$ & & & $x$ & $x$ & & & $x$ \\
\hline [62] & & $x$ & & & & & & & $x$ \\
\hline [22] & & & $x$ & $x$ & & & $x$ & $x$ & $x$ \\
\hline [63] & $x$ & & & & $x$ & & & & \\
\hline [64] & $x$ & & & $x$ & & $x$ & & & \\
\hline [29] & & $x$ & & & $x$ & & & & \\
\hline [65] & & & & $x$ & $x$ & & & & \\
\hline [66] & & & & $x$ & & & & & $x$ \\
\hline [67] & & & $x$ & $x$ & & & & $x$ & $x$ \\
\hline [68] & $x$ & & & $x$ & & $x$ & & & $x$ \\
\hline [69] & & & & $x$ & & $x$ & $x$ & & $x$ \\
\hline [70] & $x$ & & & & & $x$ & & & $x$ \\
\hline [71] & & & & $x$ & & & $x$ & & \\
\hline [72] & & & & $x$ & & & $x$ & & \\
\hline
\end{tabular}




\section{SLR Findings and Discussion}

The selected articles confirm that, in recent years, researchers have focused their efforts towards understanding the actual possibility of integrating lean and green practices in order to reach a higher level of sustainability. In fact, according to Figure 340 (88.8\%) of the selected articles have been published after 2010. Nevertheless, it is important to highlight that, despite the great efforts found in the literature towards investigating the combined approach, only 45 articles have been found in the literature explicitly addressing this issue, demonstrating that too much research has still to be conducted in this direction $[9,10,28]$.

Regarding the way in which researchers in the field have addressed the lean-green issue, the majority of the articles in the SLR, specifically 24 (53.3\%) of them, study the integration of lean and green practices from a general and theoretical point of view. In particular, $14(31.1 \%)$ of them are literature reviews and $10(22.2 \%)$ perform conceptual analyses. On the other hand, $12(26.6 \%)$ articles address the combination issue from a more practical point of view, proposing integration frameworks and approaches based on simulations and (when available) benchmark data, whereas 19 (42.2\%) conduct empirical case studies. The lack of further practical analyses is probably due to the fact that, since the idea of implementing lean and green practices together is relatively new, there are not many companies that have already adopted such a combined approach, making researchers to resort to simulations, theoretical analyses and pilot experiments to test their research hypotheses and proposals.

Regarding the technical content of the selected articles, several researchers have focused their attention on studying lean and green practices concurrent and divergent points in order to provide a useful starting point for developing their combination strategy. In particular, 16 (35.5\%) articles have been published with this purpose. These contributions are discussed in Section 4.1. In this same line, researchers have also focused their attention in analysing to what extent lean and green practices, with their similarities and differences, are compatible and can yield improved results when being combined. Contributions in this direction have been found in $15(33.3 \%)$ articles and are discussed in Section 4.2. The conducted SLR includes $21(46.6 \%)$ articles where different approaches have been proposed to implement the combination of lean and green practices. These contributions are discussed in Section 4.3. Finally, in Section 4.4 the contributions of the 30 (66.6\%) articles that explicitly report results in terms of the companies' sustainability performances are discussed.

\subsection{Lean vs. Green Manufacturing: Similarities and Differences}

Most of the articles studying the main similarities and differences between lean and green practices conclude that both practices are complementary and, to some extent, overlapping. In general, researchers agree that, although lean and green practices do differ in their main objectives, being the former mainly focused on adding value to customers while reducing the resource and time consumptions, and the latter focused on reducing the environmental footprint throughout the whole product life, their main similarity, which is waste reduction, appears to be obvious [10,59]. According to [29], both practices are aimed at minimising (ideally eliminating) waste, no matter what type of waste they are focused on. Researchers in [29] and [37] agree with the observations reported in [59] and [26]. Nevertheless, they further suggest that the different methods for reducing such wastes and, even more important, the different definitions of what wastes are, are indeed the main conflicting points between lean and green practices. In the same line, authors in [29] state that green practices go further than lean ones, being concerned not only in waste reduction but also in process efficiency and optimization of raw material consumption. Researchers in [29] also highlight that the main difference between lean and green practices is the waste definition, arguing that while lean practices are focused on workforce and space reduction as well as increasing flexibility and capacity utilisation, green practices are aimed at reducing, reusing, recycling, reworking, returning, and remanufacturing. On the other hand, in [59] it is argued that, although lean and green wastes definition can differ, lean non-value added activities can be considered as energy and natural resources wastage, associating the seven lean wastes with the wastes defined within the green manufacturing context. 
Finally, according to the articles selected in the SLR conducted in this paper, most researchers in the field highlight waste reduction philosophy [57], resource productivity, organisational change, and source reduction [29], among the main similarities between both practices; whereas identify their main focus [63], the waste definition [63], the type of customer, the manufacturing strategies, some adopted methods, techniques, tools and practices [29], and the EOL strategies [37], as their main differences. These similarities and differences are further summarised in Table 3.

Table 3. Lean vs. Green manufacturing.

\begin{tabular}{|c|c|c|}
\hline Manufacturing Philosophy & Lean & Green \\
\hline Main focus & $\begin{array}{l}\text { Increase value to customers while } \\
\text { reducing the resource and time } \\
\text { consumptions via waste } \\
\text { elimination [45]. }\end{array}$ & $\begin{array}{l}\text { Reduce environmental footprint } \\
\text { and minimise health risks } \\
\text { throughout the entire product life } \\
\text { cycle [37]. }\end{array}$ \\
\hline Basic principles & $\begin{array}{l}\text { Lean principles [73]: } \\
\text { - Long-term thinking } \\
\text { - Elimination of wastes } \\
\text { - People commitment } \\
\text { - Continuous improvements }\end{array}$ & $\begin{array}{l}\text { Green principles are mainly } \\
\text { focused on [74]: } \\
\text { - Pollution prevention } \\
\text { - Reduction of toxic substances } \\
\bullet \quad \text { DfE }\end{array}$ \\
\hline Waste & $\begin{array}{c}\text { Lean } 7 \text { wastes [29]: } \\
\bullet \text { Transport } \\
\bullet \text { Inventory } \\
\bullet \text { Motion } \\
\bullet \text { Waiting } \\
\text { - Over-processing } \\
\text { - Over-production } \\
\bullet \text { Defects }\end{array}$ & $\begin{array}{l}\text { Green wastes [74]: } \\
\bullet \quad \text { Solid wastes } \\
\text { - Hazardous wastes } \\
\text { - Air emissions } \\
\text { - Wastewater discharges }\end{array}$ \\
\hline Methods/tools & $\begin{array}{l}\text { Well-defined, documented and } \\
\text { widely used standard methods } \\
\text { and tools [38]. }\end{array}$ & $\begin{array}{l}\text { Although different tools, such as, } \\
\text { LCA, DfE and EOL strategies are } \\
\text { widely used, green practices are } \\
\text { usually based on customised } \\
\text { approaches [38]. }\end{array}$ \\
\hline Product design & $\begin{array}{l}\text { Design is focused in increasing the } \\
\text { quality and performance, while } \\
\text { reducing costs [75]. }\end{array}$ & $\begin{array}{l}\text { Design, including tools such as } \\
\text { DfE, focuses on decrease scrap in } \\
\text { many areas of the product life } \\
\text { cycle by planning waste reduction } \\
\text { from the first stages of the } \\
\text { production [57]. }\end{array}$ \\
\hline Inventory & $\begin{array}{c}\text { Replenishment frequencies are } \\
\text { increased [57]. }\end{array}$ & $\begin{array}{l}\text { High replenishment frequencies } \\
\text { imply higher emissions, so } \\
\text { replenishment frequencies need to } \\
\text { be reduced [76]. }\end{array}$ \\
\hline Pollution & $\mathrm{CO} 2$ emission is not reduced [76]. & $\begin{array}{l}\text { Reduces any pollution that } \\
\text { happens during the production } \\
\text { process [77]. }\end{array}$ \\
\hline Supply chain & $\begin{array}{l}\text { Close cooperation with suppliers } \\
\text { [77]. }\end{array}$ & $\begin{array}{l}\text { Suppliers' involvement is crucial } \\
\text { since environmental footprint } \\
\text { should be minimised throughout } \\
\text { the entire product life cycle } \\
\text { including its EOL. }\end{array}$ \\
\hline Product EoL & $\begin{array}{l}\text { No concern for product use impact } \\
\text { or EOL recovery [37]. }\end{array}$ & $\begin{array}{l}\text { Includes EOL strategies into the } \\
\text { product life cycle for which the } \\
\text { company is responsible [37]. }\end{array}$ \\
\hline Costumers & $\begin{array}{l}\text { Customers are focused on high } \\
\text { quality and low priced services } \\
\text { and products [37] }\end{array}$ & $\begin{array}{l}\text { Customers are focused on services } \\
\text { and products that are produced in } \\
\text { an eco-friendly way [37]. }\end{array}$ \\
\hline
\end{tabular}




\subsection{Can lean and Green Practices be Integrated into a Single Combined Approach?}

The conflicting opinions discussed in Section 4.1, show that the discussion about which are the common and conflicting points between lean and green practices is still open. Consequently, so it is the discussion regarding whether they are actually compatible and suitable to work together. In addition, not only too little empirical evidence of successful cases adopting lean-green approaches can be found in the literature [10], but also the results that can currently be found are conflicting [59]. On one hand, there are researchers that argue that lean and green practices can work together since they can be concurrent generating a synergy regarding waste reduction, energy, material and time consumption, supply chain management and product life cycle optimisation [9-11,28,29,47,56]. On the other hand, there are the ones that state that lean and green practices are not always compatible, existing some areas where combining them can be particularly hard [29,41,78]. For example, the inventory level is one of the most critical aspects when combining lean and green approaches. In this case, while lean practices focus on producing, transporting and packing small lot sizes to fulfil customers' requirements, the high replenishment frequency can imply higher emissions and more packaging wastes, contradicting green principles.

In general, researchers who are reluctant to combine both approaches are concerned about whether lean practices, which are focused on waste reduction from the customers' added value perspective, optimising cost, quality and lead times, will still be profitable after incorporating green practices focused on environmental objectives which are not always in line with lean objectives. In this line, authors in [63] suggest that the main strategic challenge consists in deciding how to implement green practices in combination with lean ones, without diminishing the potential profitability achieved by the latter, while being able to keep the balance between economic, environmental and social performances. Moreover, in [79] it is stated that, within a combined framework, lean practices will not always be able to limit the negative impact on operational aspects that green practices could have, being also true the other way around. Finally, in [9], authors also state that lean-green approaches will have to face the same challenges that lean and green practices have to face when implemented individually. For instance, in [26], it is highlighted that, as it is usually the case of green practices, in order to implement the lean-green approach, practitioners should have to resort to customised approaches; whereas in [64], it is stated that one of the main barriers for the implementation of the lean-green approach is the fact that a huge investment in equipment is required.

On the other hand, there are many researchers that agree that, although lean and green manufacturing approaches are not completely compatible and do differ in their main focus, to be aware of their similarities and differences and, even more important, to be capable of handling them, can indeed give practitioners the opportunity to improve both methods so that they can efficiently match. In this line, researchers who favour the integration have further studied lean and green compatibility (beyond their similarities and differences), evaluating to what extent lean and green practices can be synergetic, in such a way that they can obtain better performance when being implemented together than when summing their individual performances. According to [56], the synergetic hypothesis is suitable since there exists a similar structure for the implementation of successful lean and green practices. In the SLR conducted in this paper, 14 (31.1\%) articles address the lean-green compatibility issue from the synergetic point of view. In [69], empirical results evaluating the lean and green synergetic effects within the supply chain are reported based on survey data collected by the Global Manufacturing Research Group (https://gmrg.org/) in European countries. In [68], the analysis of three pollution-prevention projects implemented by two large multinational companies have been conducted. According to [68], lean and green practices can generate sequential or reciprocal interactions, supporting each other, working in a complementary and synergetic environment. In [47], semi-structured interviews with interdisciplinary teams responsible of integrating lean and green practices in two manufacturing companies in the UK, are conducted. Experimental results in [47] show that the synergetic effect generated by lean and green practices lead to several benefits, such as fostering innovations and reducing the production costs of eco-friendly products. In addition, authors 
in [47] highlight that, in order to achieve the synergetic effects, it is usually required to customise the companies' operational profile as well as to ensure collaboration with suppliers. In [58], authors state that companies looking for being lean will have more success if they also seek green objectives. In the same line, several researchers in the field who have largely discussed about "how green can be lean", such as the ones in [11] and [41], have concluded that, since lean practices are not aimed at green objectives, they cannot replace green practices towards achieving green results, but they can provide a continuous improvement, flexible and employees' engagement culture creating a suitable and highly favouring environment for the implementation of green initiatives. Authors in [76], agree with these observations, stating that the lean culture can be a catalyst for green practices, facilitating the adoption of environmental practices. Moreover, a particular example of such catalytic effect can be found in [37], where it has been proved that the impact of lean practices on operational supply chain performance can be improved by preventing pollution and recycling.

\subsection{Lean-Green Approach: State-of-the-Art Implementations}

Although the synergetic effects of implementing lean and green practices in an integrated environment have been demonstrated by several researchers in the field $[10,11,26,53,56,70]$, there is still a lack of suitable integration and combination strategies proposed in the literature as well as a lack of evidence of successful practical cases reported in the literature [10,28,47]. In particular, according to authors in [28], the research gap is still deeper when trying to evaluate the combined approach performance in terms of sustainability improvements due to the lack of sustainability metrics. In addition, most of the current proposed approaches in the literature are customised since lean-green approaches should fulfil different particular needs of the companies, related with local culture, policies and regulations.

In general, researchers agree that different combination schemes, such as, sequential and parallel, can be adopted to integrate lean and green practices [28]. In this line, there are the ones that propose to combine them into a new, single and stand-alone lean-green approach [47], while there are others that, based on the fact that lean practices are not only well-documented but also widely (and successfully) adopted all over the world, as well as that the lean culture do favour the implementation of green initiatives, propose to use an already stablished lean environment as a catalyst to the adoption and further incorporation of green practices $[43,44,53]$. Within the first group, waste management methods, like Waste Reducing Techniques (WRT), are the most used strategies to perform the combination $[37,38,41,60]$. In [53], a combined approach based on the Theory of Inventive Problems-Solving tools, is presented. Researchers in [38] assume that green and lean practices have mutually exclusive design requirements and propose to combine them into the same system based on a waste contradiction matrix. In [38], a waste minimisation framework based on an advanced 3R (Reduction-Reuse-Recovery) method, is proposed. In addition, although there is a strong tendency of using waste management methods, some other approaches have been proposed to address the combination from the first group's perspective. In [60], the multiple attribute utility theory method is used for assessing a lean-green supply chain. In [50], a Green Lean Total Quality (GLTQ) Information Management System (IMS), which is an IMS within the context of an Environmental Management System (EMS), integrated to Total Quality Management (TQM) and lean principles, is proposed. In this way, authors in [71] intend to achieve total communication efficiency based on a green-lean TQM system, demonstrating that the proposed approach allows generating more revenues and also providing Research and Development facilities. In [71], a combined lean-green approach based on the integration of management systems, such as ISO 9001 and 14001, is proposed. In [47], an Analytical Hierarchical Process (AHP) is used to integrate Total Preventive Maintenance (TPM) and ISO 14001principles into a lean-green combined framework. In [72], a case study is conducted on different Alsatian industrial companies in order to develop a lean-green management framework based on lean indicators as well as green performance and intentions indicators. 
Within the second group, several researchers have proposed to incorporate green practices to manufacturing processes that have already adopted a lean philosophy. In this line, one of the most frequently proposed approaches consists in taking advantage of the flexible nature of lean practices by modifying and adapting them so that they can work in combination with green practices towards the same objectives. In particular, the most frequently reported adapted lean tools are Value Stream Mapping (VSM) [42,43,46] and Continuous Improvements (CI) principles [48]. In [69], the implementation of lean and green practices combined within a CI culture in a Small and Medium Enterprise (SME) foundry is studied. In [69], VSM is adapted to address environmental and production wastes. In [42], the VSM tool is proposed for determining waste, in terms of measuring the carbon dioxide emissions particularly across organisational boundaries within the context of a food industry. In [48], a green-lean business model based on five principles, viz., stable value stream, identification of environmental impacts, measurement and improvement of the environmental value streams, and CIs, is developed for a global engineering company. In [43], a novel lean-green metric integrating metrics derived from lean and green implementations, is proposed. In [45], a new lean-green combined approach based on a Carbon-Value Efficiency is proposed. Experimental results in [45] show that the proposed approach is not only capable of reducing the carbon footprint but also the production lead time.

Finally, it is important to mention that, although lean as well as green practices do include activities that can be implemented throughout different areas of the company, addressing different stages of the productive process, the articles included in the SLR show a strong tendency of implementing and evaluating the lean-green approach within the context of Supply Chain Management (SCM) [37,45]. In fact, although there are the ones that reports the combination of both practices to address other manufacturing issues, such as, metrics [46,48], quality [46], safety [50], lead time [28], customer service [50], cost [50], inventory [50] and transportation [58], there exists the need for more research regarding the different production stages [58]. In addition, in [26] and [42] it is stated that there is a lack in the literature regarding empirical evidence of practical implementation of the combined lean-green approach. Among the $21(46.6 \%)$ articles found in the SLR proposing practical strategies for the lean-green approach implementation, $8(17.7 \%)$ have reported results obtained within the real manufacturing scenario. In particular, results from different manufacturing contexts, such as construction projects [22], metal stamped parts production [42], Swedish industry [45], food industry [28], part production in the automotive sector [48], and Chinese Fashion AutoParts industry [52], and SME foundry [54], has been identified. In [69], authors go even further, presenting the results obtained by implementing the proposed lean-green approach in different companies, with different sizes and operating in a different business area, giving researchers in the field valuable benchmark data allowing them to expand their approaches to other companies and manufacturing sectors.

In order to summarise the findings discussed in this section, Figure 4 shows the most relevant contributions found in the SLR towards the integration of lean and green practices, in terms of the main proposed approaches, their objectives and their main impacts on the companies' performance. 


\begin{tabular}{|c|c|c|c|c|}
\hline \multicolumn{2}{|c|}{ Objectives } & \multirow{2}{*}{\multicolumn{2}{|c|}{ Approach }} & \multirow{2}{*}{ Performance Impact } \\
\hline Business agility & \multirow{2}{*}{$\begin{array}{l}\text { Production } \\
\text { Efficiency }\end{array}$} & & & \\
\hline Sustainability & & \multirow{2}{*}{$\begin{array}{l}\text { Lean practices as a catalyst to } \\
\text { GSCM }\end{array}$} & \multirow{2}{*}{$\begin{array}{l}\text { VSM adapted to simultaneously assess } \\
\text { environmental and production wastes }\end{array}$} & Sustainability \\
\hline \multirow{4}{*}{$\begin{array}{l}\text { Innovative, } \\
\text { environmental } \\
\text { friendly and } \\
\text { profitable } \\
\text { manufacturing }\end{array}$} & \multirow{4}{*}{$\begin{array}{c}\text { Competitiveness } \\
\begin{array}{c}\text { Environmental } \\
\text { Eficciency }\end{array}\end{array}$} & & & Environmental \\
\hline & & Waste management model & Lean-Green simultaneous model & Economic \\
\hline & & Lean-Green Parallel model & Lean-Green sequential model & Social \\
\hline & & \multicolumn{2}{|c|}{ Lean-Green model based on Waste Reduction Techniques (WRT) } & Public image \\
\hline \multirow{2}{*}{$\begin{array}{l}\text { Reduce energy } \\
\text { consumption }\end{array}$} & \multirow[t]{2}{*}{ Long term success } & \multirow{2}{*}{\multicolumn{2}{|c|}{$\begin{array}{l}\text { Lean-Green approach based on an easy-to-track metric called Carbon- } \\
\text { Value Efficiency }\end{array}$}} & Business \\
\hline & & & & Cultural \\
\hline Quality & $\begin{array}{l}\text { Reduce CO2 } \\
\text { emissions }\end{array}$ & \multicolumn{2}{|c|}{$\begin{array}{l}\text { VSM for determining waste, in terms of measuring the carbon dioxide } \\
\text { emissions }\end{array}$} & Competitiveness \\
\hline \multirow{2}{*}{$\begin{array}{l}\text { ISO standard } \\
\text { compliance }\end{array}$} & \multirow{2}{*}{$\begin{array}{l}\text { Pollution } \\
\text { prevention }\end{array}$} & \multicolumn{2}{|c|}{ Utility theory method for assessing a supply chain. } & Product Quality \\
\hline & & Green Lean Total Quality (G & Information Management System & Overall \\
\hline \multirow[t]{2}{*}{$\begin{array}{l}\text { Improve social } \\
\text { responsibility }\end{array}$} & \multirow{2}{*}{$\begin{array}{l}\text { Reduce waste } \\
\text { generation }\end{array}$} & \multirow{2}{*}{\multicolumn{2}{|c|}{$\begin{array}{l}\text { Kaizen approach for improving mass and energy flows of manufacturing } \\
\text { environment that already possesses a basic deployment level in applying } \\
\text { lean. }\end{array}$}} & Organisational \\
\hline & & & & Production \\
\hline Nerdice & \multirow{2}{*}{$\begin{array}{c}\text { Satisfy } \\
\text { stakeholders }\end{array}$} & \multirow{2}{*}{\multicolumn{2}{|c|}{$\begin{array}{c}\text { The combined approach of lean fundamental thinking with green } \\
\text { manufacturing perspective analyzed with TRIZ (Theory of Inventive } \\
\text { Problems-Solving) methodology }\end{array}$}} & Material efficience \\
\hline $\begin{array}{l}\text { Improve customer } \\
\text { service }\end{array}$ & & & & Social responsability \\
\hline \multirow{5}{*}{\multicolumn{2}{|c|}{ Add extra value to the product }} & \multirow{2}{*}{\multicolumn{2}{|c|}{$\begin{array}{l}\text { Integration between formal management systems, such as ISO } 9001 \text { and } \\
\text { 14001, and industrial practices from integrating management systems with } \\
\text { company-specific production systems (XPS) }\end{array}$}} & Manufacturing costs \\
\hline & & & & Manufacturing facility \\
\hline & & \multicolumn{2}{|c|}{$\begin{array}{l}\text { Nested Integrated Cross-Entropy (NICE) method to solve the proposed } \\
\text { mixed-integer nonlinear mathematical model }\end{array}$} & Market \\
\hline & & \multirow{2}{*}{\multicolumn{2}{|c|}{$\begin{array}{l}\text { Lean-Green Business Model based on stable value stream, identification of } \\
\text { environmental impacts, measurement and improvement of the } \\
\text { environmental value streams, and continuous improvement }\end{array}$}} & Manufacturing times \\
\hline & & & & Financial \\
\hline
\end{tabular}

Figure 4. Summary of the proposed lean-green approaches in the SLR: Main concerns, proposed approaches, and their performance impact. 


\subsection{Lean-Green Approach and Its Link with Sustainability}

As discussed in Section 1, unlike lean practices, that are mainly aimed at operational and financial aspects, and green practices, that are mainly aimed at environmental aspects, the lean-green approach has been born to address the three pillars of sustainability, viz., economic, environmental and social ones, simultaneously. In this sense, there is a tight relationship between the lean-green concept and sustainability, being sustainability one of the main objectives of the lean-green manufacturing approach. Then, it is not surprising that many of the articles selected for the SLR evaluate their performances in terms of sustainability improvements. In particular, $30(66.6 \%)$ of them explicitly report results in terms of the companies' sustainability performances. In general, the authors of these articles agree that, provided the synergetic effect is achieved, the lean-green approach can lead to improvements on economic, environmental and social performances simultaneously [14,43,45,69]. Moreover, in [66] it is stated that the integration of lean and green practices into a combined approach is the key aspect towards achieving a superior sustainability performance.

The SLR conducted in this paper shows that, in recent years, promising sustainability results have been reported in the literature when implementing the lean-green combined approach. Moreover, many of these results have been obtained within the context of real manufacturing scenarios, suggesting that several efforts have been done towards filling the research gap highlighted in [28] and [26] regarding the lack of empirical evidence of successful lean and green integration cases in the real manufacturing scenario. In particular, 19 (42.2\%) articles evaluate the potential and actual sustainability performance improvements that the lean-green approach implementation can achieve within real manufacturing scenarios, such as the construction of a hospital [22], an European motorcycle component manufacturer [42], a Swedish industry [44], a food industry supply chain [28], an Indian automotive sector [48], a Chinese Fashion Auto Parts suppliers [52], foundry SMEs [67], and Alsatian industrial companies [45], among others.

Most of the articles in the SLR conduct a qualitative analysis of the achieved sustainable results. For instance, in [48] a literature review is conducted within the context of an Indian automotive SME industry, reporting improvements regarding productivity, by constantly enhancing the business efficiency and effectiveness, when combining lean and green practices. In [67], a literature review is conducted within the context of foundry SMEs, suggesting that lean and green management strategies should be implemented in a CI context in order to achieve sustainable continuous improvements. Nevertheless, in [59] it is stated that, to fully address sustainability aspects, it is crucial to develop standard and benchmark sustainability metrics. Although 30 articles in the SLR evaluate their performances in terms of sustainability, only $3(6.6 \%)$ conduct a quantitative analysis by defining new metrics related to it $[28,45,50]$. In [46], a carbon-value efficiency metric is defined to measure the performance of a metal stamped parts production process, showing improvements in terms of the carbon-value efficiency, production lead time and carbon footprint. In [60], the multiple attribute utility theory method is proposed to measure the performance of supply chains in terms of managerial and environmental performances. In [50], a lean-green management framework is developed on the basis of lean and green indicators, allowing companies to benchmark their lean and green practices. Finally, in [46] it is further highlighted that, for the sake of succeeding in the implementation of lean-green approaches, companies not only need to have access to benchmark sustainability metrics, but they also to fully consider operational, cultural and business opportunities.

Finally, in order to give researchers and practitioners a useful starting point towards considering sustainability objectives by implementing lean-green manufacturing, Table 4 summarises the most recurrent and relevant success factors pointed out by the authors of the articles in the SLR that have already achieved promising sustainable results by implementing the lean-green combination. 
Table 4. Main success factors towards achieving sustainability performance by implementing the lean-green approach.

\begin{tabular}{|c|c|}
\hline Success Factor & Source \\
\hline $\begin{array}{c}\text { The lean-green approach implementation should be gradual, allowing companies to set } \\
\text { priorities, and identify key goals. }\end{array}$ & [64] \\
\hline Operational roles and responsibilities need to be broadened to include sustainability issues. & [22] \\
\hline Sustainability metrics should be developed. & [28] \\
\hline $\begin{array}{c}\text { There is a need for openness of employees, stakeholders, customers, leaders and suppliers } \\
\text { towards innovation. }\end{array}$ & [28] \\
\hline $\begin{array}{c}\text { Effective information management is crucial towards reaching sustainability } \\
\text { improvements. }\end{array}$ & [71] \\
\hline Management commitment is crucial for achieving sustainability standards. & [71] \\
\hline $\begin{array}{l}\text { A lean working environment, consisting in trained, engaged and committed employees, as } \\
\text { well as continuous improvements culture, favours the implementation of green initiatives } \\
\text { in combination with lean practices towards sustainability. }\end{array}$ & [37] \\
\hline Customer focus and integration is crucial to achieve sustainable results. & [71] \\
\hline $\begin{array}{c}\text { A key aspect towards implementing innovative lean-green approaches is to ensure system } \\
\text { and process change management. }\end{array}$ & [37] \\
\hline $\begin{array}{c}\text { Effective planning is needed towards combining lean and green practices in a synergetic } \\
\text { way. }\end{array}$ & [64] \\
\hline Team and end-to-end supply chain integration is crucial to achieve sustainable results. & {$[50,64]$} \\
\hline $\begin{array}{l}\text { It is usually needed to customise the lean-green approach in order to fulfil the particular } \\
\text { needs of the companies. }\end{array}$ & [48] \\
\hline $\begin{array}{l}\text { The adoption of a continuous improvement culture is crucial towards implementing a } \\
\text { lean-green approach and obtaining sustainable results. }\end{array}$ & [45] \\
\hline $\begin{array}{c}\text { Benchmarking of suppliers against each other can help to implement lean-green strategies } \\
\text { more efficiently. }\end{array}$ & [69] \\
\hline $\begin{array}{l}\text { Strong communication and coordination between different sectors are crucial for being able } \\
\text { to implement the lean-green approach. }\end{array}$ & [46] \\
\hline $\begin{array}{l}\text { Evaluation and review of performance and progress towards targets can lead to } \\
\text { improvements in the sustainable results. }\end{array}$ & [71] \\
\hline $\begin{array}{l}\text { Wide understanding, acceptance and adoption of lean and green concepts are needed } \\
\text { towards being able to actually implement them together in a synergetic way. }\end{array}$ & [45] \\
\hline $\begin{array}{l}\text { Understanding of lean contributions towards implementation of green initiatives helps to } \\
\text { take advantage of lean culture as a catalyst for green practices. }\end{array}$ & {$[37,77]$} \\
\hline
\end{tabular}

\section{Conclusions and Final Remarks}

Along with the important contributions of lean and green practices towards sustainability, researchers have concluded that lean and green implementations as stand-alone systems are usually not enough to ensure the balance between the three pillars of sustainability, viz., economic, environmental and social ones, demanded by the current global market. In this line, they have suggested combining lean and green practices into a single manufacturing approach. Nevertheless, the lean-green manufacturing concept is still a new idea, lacking evidence of its practical implementation. In addition, due to the lack of widely used and standard sustainability metrics, the research gap becomes deeper when evaluating the combined approach performance in terms of sustainability improvements. In this paper, a SLR has been conducted in order to evaluate the actual possibility of implementing the lean-green combination. On one hand, the analysis of the concurrent and divergent points between both practices as well as the synergetic effects they can achieve when being implemented together have been analysed. On the other hand, the main implementation strategies in the state-of-the-art have been introduced, and the most concerning challenges reported in the literature regarding such implementation have also been discussed. Finally, the link of the combined lean-green approach with sustainability has been explored by analysing the different sustainability performance results reported in the literature, in terms of simultaneous improvements in economic, environmental and social performances.

According to the conducted SLR, the theoretical and practical evidence regarding whether lean and green practices are compatible and capable to work together is still not conclusive. On one hand, 
there are researchers that argue that there are several areas, such as the inventory level, where lean and green practices can pursue contradictory objectives making their combination particularly hard. In such a context, they are concerned with regarding whether lean practices can still be efficient after implementing green ones. On the other hand, different survey studies in the literature have shown that, since lean and green practices can be implemented using a similar structure, they can generate a synergetic environment, either working sequentially or in parallel, optimising waste, energy, material, time and supply chain management. In this line, some researchers emphasise the fact that the lean culture provides a continuous improvement, flexible and employees' engagement context, which favours the implementation of green initiatives. These researchers suggest using an already stablished lean environment as a catalyst to the adoption and further incorporation of green practices. In particular, according to the conducted SLR, the most frequently adapted lean tools to incorporate green practices are VSM and CI. Some successful evidence of this combination strategy has been found in the conducted SLR, especially within the supply chain area. Some other researchers suggest combining the lean and green practices into a single stand-alone approach resorting to waste management methods like WRTs, information management methods and quality management methods, such as TQM and TPM. Finally, beyond the different technical issues encountered when implementing the lean-green approach, all the researchers in the field agree that one of the main barriers to adopt lean-green manufacturing is the fact that a huge investment in equipment is required. In addition, they recognize that, in order to achieve successful results, it is usually required to customise the companies' operational profile and ensure collaboration with suppliers.

Regarding the capability of lean-green manufacturing of improving the companies' sustainability performance, the conducted SLR show promising results achieved by qualitative studies carried out within the contexts of different manufacturing environments, such as construction, food and automotive industries. In particular, many of these studies are surveys, being a lack of quantitative studies in the literature. In fact, only 3 articles analyse sustainability results quantitatively. In this line, researchers agree that, in order to fully address sustainability aspects, it urges to further develop well-defined, robust and standard sustainability metrics. In this same line, there is a lack of benchmark data and results, making it even more difficult to test the proposed approaches and compare their performance with the ones available in the state-of-the-art.

Finally, based on the conducted SLR, several success factors to improve sustainable results based on the lean-green approach implementation have been identified. These success factors provide useful theoretical and practical considerations as well as different implementation tools that can be used by researchers and practitioners as a starting point towards the adoption of lean-green practices. In this sense, it is the authors' intention that the discussion presented in this paper can encourage researchers and practitioners to adopt the lean-green approach for improving sustainability aspects of their business.

Author Contributions: Conceptualization, W.A. and K.S.; methodology, W.A. and M.A.; analysis, W.A.; investigation, W.A.; resources W.A., K.S. and A.A.-A.; writing-original draft preparation, W.A.; writing-review and editing, K.S., A.A.-A. and M.A.; supervision, K.S. and A.A.-A. All authors have read and agreed to the published version of the manuscript.

Funding: This research received no external funding.

Conflicts of Interest: The authors declare no conflict of interest.

\section{References}

1. Bortolotti, T.; Boscari, S.; Danese, P. Successful lean implementation: Organizational culture and soft lean practices. Int. J. Prod. Econ. 2015, 160, 182-201. [CrossRef]

2. Dickson, E.W.; Singh, S.; Cheung, D.S.; Wyatt, C.C.; Nugent, A.S. Application of Lean Manufacturing Techniques in the Emergency Department. J. Emerg. Med. 2009, 37, 177-182. [CrossRef] [PubMed]

3. Fliedner, G. Sustainability: A new lean principle. In Proceedings of the 39th Annual Meeting of the Decision Sciences Institute, Baltimore, MD, USA, 22-25 November 2008. 
4. Dieste, M.; Panizzolo, R. On the Relationship between Lean Practices and Environmental Performance. In Proceedings of the IOP Conference Series: Earth and Environmental Science; IOP Publishing: Bristol, UK, 2018; Volume 151.

5. Govindan, K.; Azevedo, S.G.; Carvalho, H.; Cruz-Machado, V. Impact of supply chain management practices on sustainability. J. Clean. Prod. 2014, 85, 212-225. [CrossRef]

6. Junior, M.J.A.P.; Mendes, J.V. Operational practices of lean manufacturing: Potentiating environmental improvements. J. Ind. Eng. Manag. 2017, 10, 550-580.

7. Ahuja, R. Sustainable Construction: Is Lean Green? ICSDEC 2012 2012, 903-911.

8. Rao, P.; Holt, D. Do green supply chains lead to competitiveness and economic performance? Int. J. Oper. Prod. Manag. 2005, 25, 898-916. [CrossRef]

9. Garza-Reyes, J.A. Green lean and the need for Six Sigma. Int. J. Lean Six Sigma 2015, 6, 226-248. [CrossRef]

10. Garza Reyes, J.A. Lean and Green: A systematic review of the state of the art. J. Clean. Prod. 2015, 102, 18-29. [CrossRef]

11. Dhingra, R.; Kress, R.; Upreti, G. Does lean mean green? J. Clean. Prod. 2014, 85, 1-7. [CrossRef]

12. Fliedner, G.; Majeske, K. Sustainability: The new lean frontier. J. Prod. Invent. Manag. 2010, 46, 6-13.

13. Peto, O. Lean in the Aspect of Sustainability. In Club of Economics in Miskolc TMP; TMP: Miskolc, Hungary, 2012; pp. 54-58.

14. Marhani, M.A.; Jaapar, A.; Bari, N.A.A.; Zawawi, M. Sustainability Through Lean Construction Approach: A Literature Review. Procedia Soc. Behav. Sci. 2013, 101, 90-99. [CrossRef]

15. Sun, J.; Han, B.; Ekwaro Osire, S.; Zhang, H.C. Design for Environment: Methodologies, Tools, and Implementation. J. Integr. Des. Process Sci. 2003, 7, 59-75.

16. Hibadullah, S.N.; Fuzi, N.M.; Desa, A.F.N.C.; Zamri, F.I.M. Lean Manufacturing Practices and Environmental Performance in Malaysian Automotive Industry. Asian J. Financ. Account. 2013, 4, 366-374. [CrossRef]

17. Chin, T.A.; Tat, H.H.; Sulaiman, Z. Green Supply Chain Management, Environmental Collaboration and Sustainability Performance. Procedia CIRP 2015, 26, 695-699. [CrossRef]

18. Chen, Y. The driver of Green innovation and Green image. Green core competence. J. Bus. Eth. 2008, 81, 531-543. [CrossRef]

19. Gehin, A.; Zwoliński, P.; Brissaud, D. A tool to implement sustainable end-of-life strategies in the product development phase. J. Clean. Prod. 2008, 16, 566-576. [CrossRef]

20. Wagner, M.; Van Phu, N.; Wehrmeyer, W. The relationship between the environmental and economic performance of firms: An empirical analysis of the European paper industry. Corp. Soc. Responsib. Environ. Manag. 2002, 9, 133-146. [CrossRef]

21. Vogel, D. Trading Up: Consumer and Environmental Regulation in a Global Economy; Harvard University Press: Cambridge, UK, 2009.

22. Cherrafi, A.; ElFezazi, S.; Govindan, K.; Garza-Reyes, J.A.; Benhida, K.; Mokhlis, A. A framework for the integration of Green and Lean Six Sigma for superior sustainability performance. Int. J. Prod. Res. 2016, 55, 4481-4515. [CrossRef]

23. Choudhary, S.; Nayak, R.; Dora, M.; Mishra, N.; Ghadge, A. An integrated lean and green approach for improving sustainability performance: A case study of a packaging manufacturing SME in the UK. Prod. Plan. Control. 2019, 30, 353-368. [CrossRef]

24. Xu, X.S.; Walker, H.; Nairn, A.; Johnsen, T. A network approach to understanding 'green buying': A literature review. Presented at the 23rd IMP Conference, Manchester, UK, 30 August-1 September 2007.

25. Maruthi, G.D.; Rashmi, R. Green Manufacturing: It's Tools and Techniques that can be implemented in Manufacturing Sectors. Proc. Mater. Today 2015, 2, 3350-3355. [CrossRef]

26. Garza-Reyes, J.A.; Jacques, G.W.; Lim, M.K.; Kumar, V.; Rocha-Lona, L. Lean and Green-Synergies, Differences, Limitations, and the Need for Six Sigma. In IFIP International Federation for Information Processing; Springer: Berlin, Germany, 2014; pp. 71-81.

27. Kurdve, M.; Hanarp, P.; Chen, X.; Qiu, X.; Zhang, Y.; Stahre, J.; Laring, J. Use of environmental value stream mapping and environmental loss analysis in lean manufacturing work at Volvo. In Proceedings of the 4th Swedish Production Symposium, Lund, Sweden, 3-5 May 2011.

28. Kurdve, M.; Zackrisson, M.; Wiktorsson, M.; Harlin, U. Lean and green integration into production system models-Experiences from Swedish industry. J. Clean. Prod. 2014, 85, 180-190. [CrossRef] 
29. Mollenkopf, D.; Stolze, H.; Tate, W.L.; Ueltschy, M. Green, lean, and global supply chains. Int. J. Phys. Distrib. Logist. Manag. 2010, 40,14-41. [CrossRef]

30. Sundar, R.; Balaji, A.N.; Kumar, R.S. A Review on Lean Manufacturing Implementation Techniques. Procedia Eng. 2014, 97, 1875-1885. [CrossRef]

31. Paneru, N. Implementation of Lean Manufacturing Tools in GarmentManufacturing Process Focusing Sewing Section of Men's Shirt. Master's Thesis, Oulu University of Applied Sciences, Oulu, Finland, 2011.

32. Saunders, M.; Lewis, P.; Thornhill, A. Research Methods for Business Students; Pearson Education Ltd.: Essex, UK, 2012.

33. Webster, J.; Watson, R.T. Analyzing the past to prepare for the future: Writing a literature review. MIS Q 2002, 26, 13-23.

34. WCED. Report of the World Commission on Environment and Development: Our Common Future. 1987. Available online: http://www.ask-force.org/web/Sustainability/Brundtland-Our-Common-Future1987--2008.pdf (accessed on 17 August 2019).

35. Freyne, J.; Coyle, L.; Smyth, B.; Cunningham, P. Relative status of journal and conference publications in computer science. Commun. ACM 2010, 53, 124. [CrossRef]

36. Thomas, J.; Harden, A. Methods for the thematic synthesis of qualitative research in systematic reviews. BMC Med. Res. Methodol. 2008, 8, 45. [CrossRef]

37. Dües, C.M.; Tan, K.H.; Lim, M. Green as the new lean: How to use lean practices as a catalyst to greening your supply chain. J. Clean. Prod. 2012, 40, 93-100.

38. Bashkite, V.; Karaulova, T. Integration of Green thinking into Lean fundamentals by Theory of Inventive Problems-Solving Tools; DAAAM International: Vienna, Austria, 2012; pp. 345-350.

39. Standridge, C.R.; Miller, G.; Pawloski, J. A case study of lean, sustainable manufacturing. J. Ind. Eng. Manag. 2010, 3, 11-32. [CrossRef]

40. Tiwari, R.K.; Tiwari, J.K. Green lean manufacturing: Way to sustainable productivity improvement. Int. J. Eng. Res. Gen. Sci. 2016, 4, 243-262.

41. Bergmiller, G.G.; McCright, P.R. Are Lean and Green Programs Synergistic? In Proceedings of the 2009 Industrial Engineering Research Conference, Miami, FL, USA, 30 May-3 June 2009.

42. Rosenbaum, S.; Toledo, M.; Gonzalez, V. Green-lean approach for assessing environmental and production waste in construction. In Proceedings of the 20th Annual Conference of the IGLC, San Diego, CA, USA, 18-20 July 2012.

43. Pampanelli, A.B.; Found, P.; Bernardes, A.M. A Lean and Green Model for a production cell. J. Clean. Prod. 2014, 85, 19-30. [CrossRef]

44. Chiarini, A. Sustainable manufacturing-greening processes using specific Lean Production tools: An empirical observation from European motorcycle component manufacturers. J. Clean. Prod. 2014, 85, 226-233. [CrossRef]

45. NG, R.; Low, J.S.C.; Song, B. Integrating and implementing Lean and Green practices based on proposition of Carbon-Value Efficiency metric. J. Clean. Prod. 2015, 95, 242-255. [CrossRef]

46. Verrier, B.; Rose, B.; Caillaud, E.; Remita, H. Combining organizational performance with sustainable development issues: The Lean and Green project benchmarking repository. J. Clean. Prod. 2014, 85, 83-93. [CrossRef]

47. Galeazzo, A.; Furlan, A.; Vinelli, A. Lean and green in action: Interdependencies and performance of pollution prevention projects. J. Clean. Prod. 2014, 85, 191-200. [CrossRef]

48. Folinas, D.; Aidonis, D.; Triantafillou, D.; Malindretos, G. Exploring the Greening of the Food Supply Chain with Lean Thinking Techniques. Procedia Technol. 2013, 8, 416-424. [CrossRef]

49. Fahimnia, B.; Sarkis, J.; Eshragh, A. A tradeoff model for green supply chain planning:A leanness-versus-greenness analysis. Omega 2015, 54, 173-190. [CrossRef]

50. Kainuma, Y.; Tawara, N. A multiple attribute utility theory approach to lean and green supply chain management. Int. J. Prod. Econ. 2006, 101, 99-108. [CrossRef]

51. Yang, S.S.; Ong, S.K.; Nee, A.Y.C. EOL strategy planning for components of returned products. Int. J. Adv. Manuf. Technol. 2015, 77, 991-1003. [CrossRef]

52. Diaz-Elsayed, N.; Jondral, A.; Greinacher, S.; Dornfeld, D.; Lanza, G. Assessment of lean and green strategies by simulation of manufacturing systems in discrete production environments. CIRP Ann. 2013, 62, 475-478. [CrossRef] 
53. Cobra, R.L.R.B.; Guardia, M.; Queiroz, G.A.; Oliveira, J.A.; Ometto, A.R.; Esposto, K.F. “Waste” as the Common "Gene" Connecting Cleaner Production and Lean Manufacturing: A Proposition of a Hybrid Definition. Environ. Qual. Manag. 2015, 25, 25-40. [CrossRef]

54. Wu, L.; Subramanian, N.; Abdulrahman, M.D.; Liu, C.; Lai, K.H.; Pawar, K.S. The Impact of Integrated Practices of Lean, Green, and Social Management Systems on Firm Sustainability Performance—Evidence from Chinese Fashion AutoParts S. Sustainability 2015, 7, 3838-3858. [CrossRef]

55. Bortolini, M.E.; Ferrari, E.; Galizia, F.; Mora, C. A Reference Framework Integrating Lean and Green Principles within Supply Chain Management. Int. J. Econ. Manag. Eng. 2016, 10, 859-864.

56. Campos, L.M.; Vazquez-Brust, D.A. Lean and green synergies in supply chain management. Supply Chain Manag. Int. J. 2016, 21, 627-641. [CrossRef]

57. Carvalho, H.; Cruz-Machado, V. Integrating Lean, Agile, Resilience and Green Paradigms in Supply Chain Management (LARG_SCM). In Proceedings of the Third International Conference on Management Science and Engineering Management, Bangkok, Thailand, 2-4 November 2009.

58. Dawood, L.M.; Abdullah, Z.H. Effect of Manufacturing Activities on Lean-Green Management Integration. In Proceedings of the International Conference on Industrial Engineering and Operations Management, Rabat, Morocco, 11-13 April 2017.

59. Duarte, S.; Cruz-Machado, V. Modelling lean and green: A review from business models. Int. J. Lean Six Sigma 2013, 4, 228-250. [CrossRef]

60. Fercoq, A.; Lamouri, S.; Carbone, V.; Lelièvre, A.; Lemieux, A.-A. Combining lean and green in manufacturing: A model of waste management. IFAC Proc. Vol. 2013, 46, 117-122. [CrossRef]

61. Franchetti, M.; Bedal, K.; Ulloa, J.; Grodek, S. Lean and Green: Industrial engineering methods are natural stepping stones to green engineering. Ind. Eng. 2009, 41, 24-29.

62. Hallam, C.R.; Contreras, C. The interrelation of Lean and green manufacturing Practices: A case of push or pull in implementation. In Proceedings of the 2016 Portland International Conference on Management of Engineering and Technology (PICMET), Honolulu, HI, USA, 4-8 September 2016; Institute of Electrical and Electronics Engineers (IEEE): Piscataway, NJ, USA, 2016; pp. 1815-1823.

63. Johansson, G.; Winroth, M. Lean vs. Green manufacturing: Similarities and differences. In Proceedings of the 16th International Annual EurOMA Conference: Implementation-Realizing Operations Management Knowledge, Göteborg, Sweden, 14-17 June 2009.

64. Kumar, M.; Rodrigues, V.S. Synergetic effect of lean and green on innovation: A resource-based perspective. Int. J. Prod. Econ. 2018, in press. [CrossRef]

65. Gupta, V.; Narayanamurthy, G.; Acharya, P. Can lean lead to green? Assessment of radial tyre manufacturing processes using system dynamics modelling. Comput. Oper. Res. 2018, 89, 284-306. [CrossRef]

66. Aguado, S.; Álvarez, R.; Domingo, R. Model of efficient and sustainable improvements in a lean production system through processes of environmental innovation. J. Clean. Prod. 2013, 47, 141-148. [CrossRef]

67. Azevedo, S.G.; Cruz-Machado, V.; Carvalho, H.; Duarte, S. Influence of Green and Lean Upstream Supply Chain Management Practices on Business Sustainability. IEEE Trans. Eng. Manag. 2012, 59, 753-765. [CrossRef]

68. Wiengarten, F.; Fynes, B.; Onofrei, G. Exploring synergetic effects between investments in environmental and quality/lean practices in supply chains. Supply Chain Manag. Int. J. 2013, 18, 148-160. [CrossRef]

69. Wadhwa, R.S. Synergizing lean and green for continuous improvement. In IFIP International Conference on Advances in Production Management Systems; Springer: Berlin/Heidelberg, Germany, 2014; pp. 154-161.

70. Larson, T.; Greenwood, R. Perfect complements: Synergies between lean production and eco-sustainability initiatives. Environ. Qual. Manag. 2004, 13, 27-36. [CrossRef]

71. Salleh, N.A.M.; Kasolang, S.; Jaffar, A. Green Lean Total Quality Information Management in Malaysian Automotive Companies. Procedia Eng. 2012, 41, 1708-1713. [CrossRef]

72. Thanki, S.; Govindan, K.; Thakkar, J. An investigation on lean-green implementation practices in Indian SMEs using analytical hierarchy process (AHP) approach. J. Clean. Prod. 2016, 135, 284-298. [CrossRef]

73. Deif, A.M. A system model for green manufacturing. J. Clean. Prod. 2011, 19, 1553-1559. [CrossRef]

74. Womack, J.P.; Jones, D.T. Lean Thinking: Banish Waste and Create Wealth in your Corporation; Simon \& Schuster: New York, NY, USA, 1996.

75. Rehman, M.A.; Shrivastava, R.L. Green manufacturing (GM): Past, present and future (a state of the art). World Rev. Sci. Technol. Sust. Dev. 2013, 10, 17-55. [CrossRef] 
76. Venkat, K.; Wakeland, W. Is Lean Necessarily Green? In Proceedings of the 50th Annual Meeting of the ISSS, Sonoma, CA, USA, 9-14 July 2006.

77. King, A.A.; Lenox, M.J. Lean and green? An empirical examination of the relationship between lean production and environmental performance. Prod. Oper. Manag. 2001, 10, 244-256. [CrossRef]

78. Kleindorfer, P.R.; Singhal, K.; Van Wassenhove, L.N. Sustainable operations management. Prod. Oper. Manag. 2005, 14, 482-492. [CrossRef]

79. Nunes, B.; Bennett, D. Green operations initiatives in the automotive industry: An environmental reports analysis and benchmarking study. Benchmarking Int. J. 2010, 17, 396-420. [CrossRef]

(C) 2020 by the authors. Licensee MDPI, Basel, Switzerland. This article is an open access article distributed under the terms and conditions of the Creative Commons Attribution (CC BY) license (http://creativecommons.org/licenses/by/4.0/). 